\title{
Quality of Tomato (Solanum lycopersicum L.) Due to Grafting in Solanaceae of Different Species
}

\author{
João Lucas Moraes Vieira ${ }^{1}$ \& Rogério Eiji Hanada ${ }^{2}$ \\ ${ }^{1}$ Postgraduate Program in Agriculture in the Humid Tropics, National Institute for Amazonian Research, Manaus, \\ Amazonas, Brazil \\ ${ }^{2}$ National Institute for Amazonian Research, Manaus, Amazonas, Brazil \\ Correspondence: João Lucas Moraes Vieira, National Institute for Amazonian Research, Manaus, Amazonas, C.P. \\ 478, CEP 69011-970, Brazil. Tel: 55-(92)-99441-1546. E-mail: lucasjoao1991@hotmail.com
}

Received: October 21, 2018

Accepted: December 1, 2018

Online Published: February 15, 2019

doi:10.5539/jas.v11n3p188

URL: https://doi.org/10.5539/jas.v11n3p188

\begin{abstract}
The present work had as objective to evaluate the physical-chemical characteristics of commercial tomato fruits grafted on different solanaceous species. The experiment was conducted in a greenhouse, in a randomized complete block design, with four blocks and six treatments, being the rootstocks: cocona (Solanum sessiliflorum); two cultivars of eggplant (Solanum aethiopicum), Long Light Green and Big Hill; jurubebão (Solanum lycocarpum) and jurubeba juna (Solanum stramonifolium), grafted with the tomato cultivar Santa Cruz Kada, and the control treatment was represented by the self-grafted tomato. Three consecutive harvests were spaced seven days after the production stabilization, and the characteristics fruits analyzed were Total Soluble Solids ( $\left.{ }^{\circ} \mathrm{Brix}\right), \mathrm{pH}$, Titratable Acidity (percentage of citric acid) and TSS/TA. A statistically significant difference was found in the Tukey's test at 5\% probability in the titratable acidity, $\mathrm{pH}$ and fruit pulp flavor, among the evaluated treatments, while the soluble solids content did not differ between treatments in any of the harvests, but the values remained within the considered adequate for the tomato in natura in the current literature. There was a decrease in fruit flavor in all treatments, and fruit $\mathrm{pH}$ drop in all treatments with the exception of jurubebão, with the advancement of plant age, while the titratable acidity had an inverse behavior. The evaluated rootstocks can be used in the tomato crop, without prejudice to the quality of the tomato fruit produced.
\end{abstract}

Keywords: fruit quality, rootstock, Solanum lycopersicum

\section{Introduction}

The tomato (Solanum lycopersicum) is one of the most cultivated vegetables in Brazil, having a great economic and social base. The average tomato in Brazil in 2017 was $67648 \mathrm{~kg} \mathrm{ha}^{-1}$, while the average for the North was $19392 \mathrm{~kg} \mathrm{ha}^{-1}$. In the state of Amazonas, in the same harvest of $1000 \mathrm{~kg} \mathrm{ha}^{-1}$, the state with the lowest productivity in Brazil, according to the Brazilian Institute of Geography and Statistics (IBGE, 2017).

The grafting technique is an alternative for the control of soil diseases, allowing the cultivation of susceptible species in areas contaminated by pathogens, as well as to improve the physicochemical characteristics of the fruits produced, and increase yield culture (Rouphael et al., 2010). A suitable rootstock should present immunity to the disease to be controlled, good affinity to the grafted cultivar, optimal morphological conditions and not adversely affect fruit quality (Peil, 2003). Therefore, research to identify potential rootstocks in disease control should be paired with investigations of the effect of rootstock on fruit quality, since the characteristics of the fruits, such as form, color and texture of the skin or the pulp and soluble solids content can be influenced negatively or positively by the rootstock used (Lee, 1994; Flores et al., 2010).

In spite of the increase in the number of researches the increase of the agronomic potential of the crop and the control of soil pathogens through grafting and of other methods, the commercial cultivation of the tomato in the Amazon is lower in relation to the large Brazilian producing regions. The Amazon of Brazil has traditionally been dependent on tomato imports of the Midwest and Southeast part of the country, producing only 5\% of regional demand (Cheng \& Rodrigues, 1995).

The use of solanaceous native to the Amazon region as rootstocks may be a viable alternative, considering that the species have natural adaptability to the edaphic and climatic conditions of the region. Another important 
factor is that the relation with the grafting is the fact that it is a technique that does not contain the environment (Peil, 2003), and can be made in organic agriculture, in increasing use in Brazil and the world.

In this context, considering the few existing research on te subject, and its importance of controlling the diseases of soil allied to the market demand for quality fruits, the present work had as objective to evaluate the influence of different solanaceae, some native to the Amazon region, as rootstocks in tomato, on the physical-chemical characteristics of the fruits.

\section{Method}

The experiment was carried out in a dry land system at Alejo Von Der Pahlen Vegetable Experiment Station of the National Research Institute of Amazonia, located at km 14 of State Highway AM-010, in the municipality of Manaus, AM $\left(03^{\circ} 15^{\prime} 19.3^{\prime \prime} \mathrm{S}\right.$ and $\left.60^{\circ} 14^{\prime} 23.2^{\prime \prime} \mathrm{W}\right)$, in red-yellow argisol. The climate is characterized as "Afi" according to Köppen, registering an annual average of $2.450 \mathrm{~mm}$, average of $27^{\circ} \mathrm{C}$ between $24-30^{\circ} \mathrm{C}$ (Ribeiro, 1976).

It was constituted by six treatments, constituted by the rootstocks: cocona (S. sessiliflorum); two cultivars of eggplant (S. aethiopicum), one long light green (ELLG) and one big hill (EBH) the 'jurubebão' (S. lycocarpum) and a 'jurubeba juna' ( $S$. stramonifolium), both accesses wild collection of secondary vegetation in the municipality of Rio Preto da Eva/AM. The tomato of Santa Cruz Kada self-grafted represented the evidence. All rootstocks were grafted with a cultivar of tomato Santa Cruz Kada. The treatments arranged in a randomized complete block design, with four replications, and each plot consisted of five plants.

The preparation of the soil for the installation of the experiment was carried out with the aid of a microtractor equipped with rotary hoe. Soil samples collected in 0-20 cm depth, submitted to analysis at the Soil Laboratory of the Federal University of Amazonas. With the result of the analysis, the fertilization of balanced planting was carried out according to the one recommended by Ribeiro et al. (1999) for the cultivation of tomato in a protected cultivation.

The rootstock seedlings were produced in greenhouse in polystyrene trays of 128 cells filled with the commercial substrate Vivatto Slim Plus ${ }^{\circledR}$, with two seeds per cell, at a depth of 3-5 mm. At 10 days after the exit the thinning was carried out, leaving only one plant per cell. A commercial cultivar used as a graft (Santa Cruz Kada) planted 25 days after sowing of rootstocks, in the same way as above.

At 50 days after sowing of rootstocks, and 25 days after sowing of the graft (Santa Cruz Kada cultivar), when the plants were grafted from four true leaves, they were processed and grafted using the full slot type fork (Lopes \& Mendonça, 2016). The difference between the ages of plants in the moment of grafting occurred due to the difference between the speed of emergence and growth of the evaluated species.

During the first 10 days after grafting, the plants were kept in a shaded environment in order to reduce the incidence of light and dehydration of the plants. After this period, the plants were kept in the sun for another five days, are ready to transplant at 15 days after grafting. The seedlings were transplanted to beds spaced $0.90 \mathrm{~m}$ between beds and $0.6 \mathrm{~m}$ between plants. The field experiment lasted for 120 days after transplantation. The plants were drip irrigated, using drip tapes, and twice a day.

Cover fertilization was carried out in six biweekly plots, using the quantities and sources described in Table 1 . To supplement the supply of calcium and boron during the period of flowering and fruit formation, in order to reduce the incidence of apical rot, commercial leaf fertilizer SETT (Stoller®) was used. The application was carried out weekly, using $2 \mathrm{~mL}$ of the product for 20 liters of water, aiming to direct the syrup directly to the flowers and fruits 
Table 1. Coating fertilization carried out by means of fertirrigation with the use of soluble fertilizers, according to the soil analysis on Ribeiro et al. (1999)

\begin{tabular}{|c|c|c|c|}
\hline DAT* $^{*}$ & $\mathrm{~N}$ & $\mathrm{P}\left(\mathrm{P}_{2} \mathrm{O}_{5}\right)$ & $\mathrm{K}\left(\mathrm{K}_{2} \mathrm{O}\right)$ \\
\hline & \multicolumn{3}{|c|}{ 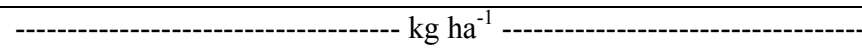 } \\
\hline 15 & 10 & 90 & 30 \\
\hline 30 & 10 & 0 & 30 \\
\hline 45 & 20 & 0 & 40 \\
\hline 60 & 20 & 0 & 40 \\
\hline 75 & 15 & 0 & 30 \\
\hline 90 & 15 & 0 & 10 \\
\hline \multirow[t]{2}{*}{ DAT* } & Urea*** & $\mathrm{MAP} * *$ & Potassium nitrate \\
\hline & \multicolumn{3}{|c|}{ - } \\
\hline 15 & 0 & 200 & 68.2 \\
\hline 30 & 2.5 & 0 & 68.2 \\
\hline 45 & 18.2 & 0 & 90.9 \\
\hline 60 & 18.2 & 0 & 90.9 \\
\hline 75 & 13.6 & 0 & 68.2 \\
\hline 90 & 13.6 & 0 & 22.7 \\
\hline
\end{tabular}

Note. *Days after transplanting; **Monoamonic phosphate: $45 \%$ in $\mathrm{P}_{2} \mathrm{O}_{5}$ and $9 \%$ in $\mathrm{N}$; ***Urea: $45 \%$ in $\mathrm{N}$; Potassium nitrate: $44 \%$ in $\mathrm{K}_{2} \mathrm{O}$ and $13 \%$ in $\mathrm{N}$.

The fruits were collected regularly, the mass determined with the help of a portable precision scale, with a precision of $0.1 \mathrm{~g}$, and the dimensions determined with a professional digital caliper Security ${ }^{\circledR}$, to determine the production of marketable fruit (CFP, in $\mathrm{g}_{\text {plant }}{ }^{-1}$ ), and the vertical (VD) and horizontal (HD) diameters of the fruits, in $\mathrm{mm}$.

To determine the physico-chemical characteristics of the fruits, five commercial fruits of each treatment were randomly collected after stabilization of the production, for three consecutive crops spaced in seven days. The fruits were harvested when a red color appeared between 10 and 30\% of the surface, and packed in expanded polystyrene trays until full ripening, being submitted to analysis in the INPA Food Analysis Laboratory INPA, to obtain: total soluble solids (TSS), pulp pH (pH), titratable acidity (TA) and the relationship between TSS and AT (flavor). Five fruits were used per replicate for analytical determination.

The TSS content was determined after grinding the fruit in a blender for 3 minutes until complete homogenization, 3 to 4 drops of the crushed pulp obtained were transferred to the prism of the Reichert ${ }^{\circledR}$ AR 200 digital refractometer, and the values were expressed directly in ${ }^{\circ}$ Brix, corrected by temperature according to the appliance manufacturer's recommendation. The $\mathrm{pH}$ of the pulp was quantified directly by the reading the crushed pulp conditioned in a $100 \mathrm{~mL}$ beker using a QUIMIS ${ }^{\circledR}$ digital potentiometer, model 400AS, duly calibrated with buffer solutions of $\mathrm{pH} 4.7$ and 10 at a temperature of $25 \pm 2{ }^{\circ} \mathrm{C}$.

The titratable acidity was determined by titration with standard solution of $0.1 \mathrm{~N} \mathrm{NaOH}$ in $25 \mathrm{~mL}$ buret, $5.0 \mathrm{~g}$ of the comminuted pulp in $50 \mathrm{~mL}$ of distilled $\mathrm{H}_{2} \mathrm{O}$ and 2 drops of the phenolphthalein indicator in Erlenmeyer's 125 $\mathrm{mL}$, obtainig the turning point when a solution reached persistent pink color for thirty seconds. The results expressed as a percentage of citric acid, assuming that this is the organic acid present in greater quantity in tomato fruits, as described by Zenebon et al. (2008). The relation between TSS and TA, as described by Kader et al. (1978) obtained the "flavor".

The data submitted to analysis of variance, and the means compared by the Tukey test, at 5\% probability, using the statistical program Assistat 7.7 (Silva \& Azevedo, 2016).

\section{Results}

A significant difference in titratable acidity detected between treatments and between harvests (Table 2). In the first harvest, the control treatment presented lower value in comparison to the other treatments, with the exception of ELLG and EBH in which it did not differ, and in the second harvest, the EBH treatment presented higher fruit titratable acidity than the control. There was no difference between the treatments in the third harvest. 
All treatments showed a titratable acidity average between the harvests higher than the control, indicating that the rootstocks led to an increase in the titratable acidity of the fruits. It has been observed in all treatments that titratable acidity tends to increase with the advancement of culture age.

It was not observed a significant difference in the TSS content of the fruits in the different treatments evaluated, nor between the evaluation periods, proving to be the variable with greater stability among the analyzed variables, either between the treatments, or between the evaluation periods, with mean of $4.86^{\circ}$ Brix (Table 3 ).

The $\mathrm{pH}$ of the fruits did not differ between the treatments in the first harvest, and in the second, it was higher in the EBH treatment in comparison to the other treatments, except for the control in which it did not differ. In the third harvest, there was no difference between the treatments compared to the control (Table 4).

There was a difference in the fruit flavor only in the second harvest, in which the fruits produced by the plants grafted on ELLG showed less flavor than the control (Table 5). There was a drop in fruit flavor over time, similar to that observed for $\mathrm{pH}$.

The CFP did not differ statistically between the tomato plants grafted with ELLG, EBH, 'jurubeba juna' and the control. Cocona grafted plants had lower CFP than control and ELLG treatment. There was no statistical difference between the treatments in relation to the $\mathrm{VD}$, and the plants grafted on cocona produced fruits with lower HD than the plants grafted in ELLG, but did not differ from the HD obtained in the control fruits (Table 6).

\section{Discussion}

A significant difference in titratable acidity detected between treatments and between harvests (Table 2).

Table 2. Titratable Acidity (TA), as a percentage of citric acid (\%), of tomato fruits grafted on different solanaceae

\begin{tabular}{lllll}
\hline \multirow{2}{*}{ Condition } & \multicolumn{4}{c}{ Harvest } \\
\cline { 2 - 4 } & 1 & 2 & 3 & \multirow{2}{*}{ Mean } \\
\hline Cocona & $0.19 \mathrm{aB}$ & $0.21 \mathrm{abB}$ & $0.27 \mathrm{aA}$ & 0.22 \\
ELLG & $0.16 \mathrm{bcB}$ & $0.22 \mathrm{aA}$ & $0.25 \mathrm{aA}$ & 0.21 \\
EBH & $0.17 \mathrm{abcB}$ & $0.16 \mathrm{bB}$ & $0.25 \mathrm{aA}$ & 0.19 \\
'Jurubebão' & $0.19 \mathrm{abB}$ & $0.21 \mathrm{abB}$ & $0.26 \mathrm{aA}$ & 0.22 \\
'Jurubeba juna' & $0.18 \mathrm{abB}$ & $0.19 \mathrm{abB}$ & $0.27 \mathrm{aA}$ & 0.21 \\
Control & $0.15 \mathrm{cB}$ & $0.16 \mathrm{bB}$ & $0.22 \mathrm{aA}$ & 0.18 \\
\hline Mean & 0.17 & 0.19 & 0.25 & 0.21 \\
CV\% & 8.7 & 14.65 & 10.67 & 7.78 \\
MSD & 0.03 & 0.05 & 0.05 & 0.04 \\
\hline
\end{tabular}

Note. The averages followed by the same lowercase letter in the column, or upper case in the rows, do not differ statistically from each other by the Tukey test at the $5 \%$ probability level.

Sirtoli et al. (2011), evaluating the development of plants and the physical-chemical characterization of Platinum hybrid, grafted and free-footed fruits, did not observe differences for the variables: water loss, texture, soluble solids, titratable acidity and SST / TA. Similar result observed by Soare et al. (2018), who evaluated the 'Lorely F1' cultivar as a graft on the 'Beaufort' rootstock, did not observe differences on the quality of the fruits produced in comparison to the free foot. Different results were observed in the present study, where a significant variation was observed in titratable acidity, $\mathrm{pH}$ and fruit flavor among treatments. This result can be explained by the different species used as rootstocks whose sap composition interferes in greater intensity with the variables analyzed, compared to grafted plants of the same species.

Riga (2015), evaluating the 'Jack' tomato grafted on nine different rootstocks, observed that the rootstocks evaluated did not affect the titratable acidity and $\mathrm{pH}$ of the fruit pulp, but influenced the total soluble solids content and TSS/TA ratio of the fruits, concluding that the evaluated rootstocks affected the fruit quality parameters compared to the non-grafted fruits, which did not occur with the evaluated rootstocks in thes work.

Bertin et al. (2000), evaluating the seasonal evolution of the quality of fresh tomato fruits grown in greenhouses under Mediterranean conditions, observed that the citric acid concentration decreased during the maturing of the plants, a result different from that found in the present study, but concluded that these interactions did not present 
a clear pattern. According to the authors, the variation in the sugar concentration in the fruit may be related mainly to the variation in dry matter content, through the dilution of sugars with the accumulation of water in the fruits, while the acid concentrations are more difficult to interpret.

The effects of plant age on the acid content of fruits are highly complex. Some studies support the hypothesis that organic acids are produced within the fruit from stored carbohydrates (Sakiyama \& Stevens, 1976), although a proportion can also be translocated from leaves and roots to fruits (Davies \& Maw, 1972). Therefore, work should be done to clearly identify the influence of the age of the plant on the AT of the fruits.

Not observed a significant difference in the TSS content of the fruits in the different treatments evaluated, nor between the evaluation periods, proving to be the variable with greater stability among the analyzed variables, either between the treatments, or between the evaluation periods, with mean of $4.86^{\circ}$ Brix (Table 3 ).

Table 3. Total Soluble Solids (TSS), in ${ }^{\circ}$ Brix, of tomato fruits grafted on different solanaceae

\begin{tabular}{lllll}
\hline \multirow{2}{*}{ Condition } & \multicolumn{3}{c}{ Harvest } & Mean \\
\cline { 2 - 4 } & 1 & 2 & 3 & 5.04 \\
\hline Cocona & 5.11 & 5.09 & 4.91 & 4.83 \\
ELLG & 4.77 & 4.81 & 4.91 & 4.66 \\
EBH & 4.63 & 4.65 & 4.69 & 5.03 \\
'Jurubebão' & 4.85 & 5.17 & 5.07 & 4.91 \\
'Jurubeba juna' & 4.95 & 4.91 & 4.87 & 4.70 \\
Control & 4.53 & 4.97 & 4.61 & 4.86 \\
\hline Mean & 4.81 & 4.93 & 4.84 & 4.50 \\
CV\% & 7.75 & 6.2 & 7.55 & 0.68 \\
MSD & 0.73 & 0.6 & 0.71 &
\end{tabular}

Note. The averages between rows and columns did not differ statistically from each other, by the Tukey test, at the $5 \%$ probability level.

According to Kader et al. (1978), for the consumption of tomato in natura the TSS content of $3.0^{\circ}$ Brix is considered ideal for high quality fruits, provided there is equilibrium with the titratable acidity. From this context, in all evaluated treatments, the fruits pulp obtained good results in relation to the TSS, that is, they are above 3.0 ${ }^{\circ}$ Brix.

Flores et al. (2010) observed in saline conditions, the increase in the content of TSS and TA of the fruits of the commercial 'Boludo' hybrid tomato, grafted on rootstock cv. Radja, who was also able to induce an increase in crop yield, concluding that grafting is a fast and efficient alternative for improving the quality of tomato fruits. Therefore, although the TSS content not influenced in the present study, the rootstock may modify this variable in the fruits.

The $\mathrm{pH}$ of the fruits did not differ between the treatments in the first harvest, and in the second, it was higher in the EBH treatment in comparison to the other treatments, except for the control in which it did not differ. In the third harvest, there was no difference between the treatments compared to the control (Table 4). 
Table 4. $\mathrm{pH}$ values of the fruits of tomatoes grafted on different solanaceae.

\begin{tabular}{lllll}
\hline \multirow{2}{*}{ Condition } & \multicolumn{3}{c}{ Harvest } & Mean \\
\cline { 2 - 4 } & 1 & 2 & 3 & 4.90 \\
\hline Cocona & $5.09 \mathrm{aA}$ & $4.97 \mathrm{cdA}$ & $4.64 \mathrm{bB}$ & 4.90 \\
ELLG & $5.16 \mathrm{aA}$ & $4.84 \mathrm{~dB}$ & $4.69 \mathrm{bC}$ & 5.14 \\
EBH & $5.19 \mathrm{aB}$ & $5.42 \mathrm{aA}$ & $4.81 \mathrm{abC}$ & 5.14 \\
'Jurubebão' & $5.24 \mathrm{aA}$ & $5.12 \mathrm{bcA}$ & $5.07 \mathrm{aA}$ & 5.01 \\
'Jurubeba juna' & $5.24 \mathrm{aA}$ & $4.97 \mathrm{cdB}$ & $4.83 \mathrm{abB}$ & 5.01 \\
Control & $5.02 \mathrm{aB}$ & $5.32 \mathrm{abA}$ & $4.77 \mathrm{abC}$ & 5.02 \\
Mean & 5.16 & 5.09 & 4.80 & 1.92 \\
CV\% & 3.20 & 2.42 & 3.84 & 0.31 \\
MSD & 0.32 & 0.24 & 0.36 & \\
\hline
\end{tabular}

Note. The averages followed by the same lowercase letter in the column, or upper case in the rows, do not differ statistically from each other by the Tukey test at the $5 \%$ probability level.

According to M. I. F. Chitarra and A. B. Chitarra (2005), when the concentration range of organic acids in vegetable juices varies between 0.5 and $2.5 \%$, consequently the $\mathrm{pH}$ decreases, being used as indicative of this variation. This situation observed in the present experiment, where all treatments with the exception of 'Jurubebão' showed a drop in $\mathrm{pH}$ of fruits with the advancement of plant age, an inverse result to that found for the titratable acidity, which increased with time.

Borguini and Silva (2007) state thet $\mathrm{pH}$ and acidity are extremely important factors when analyzing the acceptance of a product by the consumer, because excessively acidic fruits are rejected for in natura consumption. The treatments evaluated produced fruits with $\mathrm{pH}$ ranging from 4.64 to 5.42 and TA of 0.15 to 0.27 , considered low acid fruits, and this factor is not an impediment for consumer acceptance of the fruits produced by the tomato Santa Cruz Kada grafted on the evaluated rootstocks.

Sirtoli et al. (2011) observed differences between the treatments only in relation to the $\mathrm{pH}$, which varied from 3.83 to 4.3 , results lower than the found in this work. According to Rouphael et al. (2010), the pH range considered ideal for tomato fruit for in natura consumption should vary between 3.7 and 4.5 , and can be influenced by the rootstock used. Although the evaluated treatments presented higher values than those considered ideal by the authors, this variable was not influenced by the rootstocks, since the control treatment also presented a value superior to the above mentioned interval, a factor that may be related to the cultivar used.

The decrease in fruit $\mathrm{pH}$ as a function of plant age seems to be related to the nutritional question of the plant. Fontes et al. (2000), evaluating the mineral composition and fruit quality of drip irrigated tomato, as a function of increasing doses of potassium fertilizers applied by fertirrigation, observed that increases in $\mathrm{K}$ dose reduced $\mathrm{pH}$ and increased acid content in fruits, same situation that was observed in the present work with the advancement of plant age.

It is recognized that the requirement of tomato by $\mathrm{K}$ increases with the advancement of plant age, due to the greater need of the nutrient during the fruit formation phase, which leads to a greater synthesis of photoassimilates (Fontes et al., 2000). For this reason, the dose of nutrient application by cover increased during the crop cycle, with apex at 45 to 60 days after transplanting, as described in Table 1 . Thus, the higher K supply during this period favored the reduction of $\mathrm{pH}$, and the addition of AT, as previously observed by Fontes et al. (2000).

There was a difference in the fruit flavor only in the second harvest, in which the fruits produced by the plants grafted on ELLG showed less flavor than the control (Table 5). There was a drop in fruit flavor over time, similar to that observed for $\mathrm{pH}$. 
Table 5. Flavor (TSS/TA) of tomato fruits grafted on different solanaceae

\begin{tabular}{lllll}
\hline \multirow{2}{*}{ Condition } & \multicolumn{3}{c}{ Harvest } & \multirow{2}{*}{ Mean } \\
\cline { 2 - 4 } & 1 & 2 & 3 & 22.78 \\
\hline Cocona & $27.07 \mathrm{aA}$ & $24.76 \mathrm{abA}$ & $18.49 \mathrm{aB}$ & 23.03 \\
ELLG & $30.03 \mathrm{aA}$ & $21.68 \mathrm{bB}$ & $19.89 \mathrm{aB}$ & 24.40 \\
EBH & $27.00 \mathrm{aA}$ & $29.64 \mathrm{abA}$ & $19.34 \mathrm{aB}$ & 23.36 \\
'Jurubebão' & $26.04 \mathrm{aA}$ & $25.56 \mathrm{abA}$ & $19.81 \mathrm{aB}$ & 23.08 \\
'Jurubeba juna' & $27.46 \mathrm{aA}$ & $26.31 \mathrm{abAB}$ & $18.67 \mathrm{aB}$ & 26.64 \\
Control & $30.59 \mathrm{aA}$ & $30.82 \mathrm{aA}$ & $21.02 \mathrm{aB}$ & 23.88 \\
Mean & 28.03 & 26.46 & 19.53 & 8.45 \\
CV\% & 8.92 & 15.82 & 12.26 & 5.91 \\
MSD & 4.88 & 8.18 & 4.68 & \\
\hline
\end{tabular}

Note. The averages followed by the same lowercase letter in the column, or upper case in the rows, do not differ statistically from each other by the Tukey test at the $5 \%$ probability level.

The result differs from that found by Cardoso et al. (2006), who identified that the TSS/TA ratio was not affected by the grafting of the Santa Clara and Santa Cruz Kada cultivars and the Débora Plus hybrid in the Hawaii 7996 hybrid rootstock, varying between 12.6 and 15.4. The results found for the same variable were higher than those found by the authors, ranging from 18.49 to 30.82 , according to the rootstock used and the date of harvest.

The tomato fruit is considered tasty when the TSS/TA ratio is higher than 10, and high quality when the values for TA and TSS are higher than $0.32 \%$ and 3\%, respectively (Kader et al., 1978). According to this definition, the fruits produced by all evaluated treatments are considered tasty, but TA lower than 0.32 and TSS higher than 3\%.

The CFP did not differ statistically between the tomato plants grafted with ELLG, EBH, 'jurubeba juna' and the control. Cocona grafted plants had lower CFP than control and ELLG treatment (Table 6).

Table 6. Commercial fruit production (CFP), vertical diameter (VD) and horizontal diameter (HD) of Santa Cruz Kada tomato fruits grafted to different solanaceae

\begin{tabular}{|c|c|c|c|}
\hline Condition & CFP & VD & HD \\
\hline & g plant $^{-1}$ & \multicolumn{2}{|c|}{--------------------- $\mathrm{mm}$-------------------- } \\
\hline Cocona & $409.9 \mathrm{c}$ & $56.48 \mathrm{a}$ & $46.81 \mathrm{~b}$ \\
\hline ELLG & $1103.02 \mathrm{a}$ & $56.26 \mathrm{a}$ & $50.22 \mathrm{a}$ \\
\hline EBH & $869.94 \mathrm{abc}$ & $57.07 \mathrm{a}$ & $47.28 \mathrm{ab}$ \\
\hline 'Jurubebão' & $558.74 \mathrm{bc}$ & $57.22 \mathrm{a}$ & $47.53 \mathrm{ab}$ \\
\hline 'Jurubeba juna' & $840.28 \mathrm{abc}$ & $56.62 \mathrm{a}$ & $47.60 \mathrm{ab}$ \\
\hline Control & $969.82 \mathrm{ab}$ & $58.07 \mathrm{a}$ & $49.03 \mathrm{ab}$ \\
\hline Mean & 791.81 & 56.96 & 48.08 \\
\hline $\mathrm{CV} \%$ & 26.89 & 3.95 & 7.5 \\
\hline MSD & 490.36 & 2.07 & 3.32 \\
\hline
\end{tabular}

Note. The averages followed by the same lowercase letter in the column, or upper case in the rows, do not differ statistically from each other by the Tukey test at the $5 \%$ probability level.

Mendonça et al. (2017) evaluating the grafting compatibility of different species of solanaceae and interspecific hybrids, identified commercial fruit yield of $6.647 \mathrm{~kg} \mathrm{plant}^{-1}$ with the use of jurubeba juna 'CNPH 19' as a scion graft and the tomato cv. 'Ellen' as a graft, and of $5.487 \mathrm{~kg} \mathrm{plant}^{-1}$ with the interspecific hybrid of eggplant 'CNPH 222' $\times$ 'Ciça' eggplant as graft port and the same tomato as graft, production superior to that identified in this study, which can be explained by the locality of the experiment.

Thus, the present work, as well as other works, demonstrates the potential of the use of the rootstocks ELLG, EBH, 'jurubebão' and 'jurubeba juna' in the tomato crop, because they do not harm the production of plant, and have potential in the control of soil-borne diseases in the Amazon region. As there was no difference between the control and the treatments in relation to RV and HD, the rootstocks used did not influence these characteristics of 
the fruits.

Grieneisen et al. (2018), after reviewing 159 publications on grafting in vegetables, stated that most of the studies that evaluate the influence of rootstock on fruit characteristics, conclude that the rootstock does not negatively influence fruit quality (pH, AT, SST, lycopene, vitamin C, firmness and taste), but there are cases that show dramatic differences, making it imperative to carry out the research, since it is not possible to predict such variables.

\section{Conclusions}

The use of rootstocks and evaluated harvesting periods interfered in the physical-chemical characteristics of tomato fruits $\mathrm{Cv}$. Santa Cruz Kada grafted, but the analyzed variables remained within the considered suitable for tomato in natura in the current literature.

All evaluated rootstocks can be used in the tomato crop, without prejudice to the quality of the tomato fruit produced.

The cocona rootstock is not indicated for the tomato crop, because it negatively influences the commercial fruit production of the plant grafted on it.

\section{Acknowledgments}

The authors are grateful to National Research Institute of the Amazon (INPA) and National Council for Scientific and Technological Development (CNPq) for the resources to fund the research, and collaborations of researchers. We also thank the as the technical staff of the Phytopathology, Food Analysis and Electronic Microscopy laboratories, as well as to the technicians of the Alejo Von Der Pahlen Vegetable Experiment Station of the National Research Institute of the Amazon.

\section{References}

Bertin, N., Ghichard, N., Leonardi, C., Longuenesse, J. J., Langlois, D., \& Naves, B. (2000). Seasonal evolution tha quality of fresh glasshouse tomato under Maditerranean conditions, as affected by vapour pressure deficit and plant fruit load. Annals of Botany, 85, 741-750. https://doi.org/10.1006/anbo.2000.1123

Borguini, R. G., \& Silva, M. V. (2007). O conteúdo nutricional de tomates obtidos por cultivo orgânico e convencional. Revista Higiene Alimentar, 45, 41-46.

Cardoso, S. C., Soares, A. C. F., Brito, A. S., Carvalho, L. A., \& Ledo, C. A. S. (2006). Viabilidade de uso do híbrido hawaii 7996 como porta-enxerto de cultivares comerciais de tomate. Bragantia, 65(1), 89-96. https://doi.org/10.1590/S0006-87052006000100012

Cheng, S. S., \& Rodrigues, J. E. L. F. (1995). Cultura do tomateiro na Amazônia Oriental. Embrapa-CPATU. Circular Técnica, 68, 24.

Chitarra, M. I. F., \& Chitarra, A. B. (2005). Pós-colheita de frutas e hortaliças: Fisiologia e manuseio (p. 785). Lavras: UFLA.

Davies, J. N., \& Maw, G. A. (1972). Metabolism of citric and malic acids during ripening of tomato fruit. Journal of the Science of Food and Agriculture, 23, 969-979. https://doi.org/10.1002/jsfa.2740230808

Flores, F. B., Sanchez-Bel, P., Estañ, M. T., Martinez-Rodriguez, M. M., Moyano, E., Morales, B., ... Bolarín, M. C. (2010). The efectiveness of grafting to improve tomato fruit quality. Scientia Horticulturae, 125(3), 211-217. https://doi.org/10.1016/j.scienta.2010.03.026

Fontes, P. C. R., Sampaio, R. A., \& Finger, F. L. (2000). Fruit size, mineral composition and quality of trickle-irrigated tomatoes as affected by potassium rates. Pesquisa Agropecuária Brasileira, 35(1), 21-25. https://doi.org/10.1590/S0100-204X2000000100003

Grieneisen, M. L., Aegerter, B. J., Stoddard, C. S., \& Zhang, M. (2018). Yield and fruit quality of grafted tomatoes, end their potential for soil fumigant use reduction. A meta-analysis. Agronomy for Sustainable Development,38(3), 29. https://doi.org/10.1007/s13593-018-0507-5

IBGE (Instituto Brasileiro de Geografia e Estatística). (2017). Levantamento Sistemático da Produção Agrícola: Pesquisa mensal de previsão e acompanhamento das safras agrícolas no ano civil (Vol. 30, No. 12, pp. 1-82). Rio de Janeiro, Brazil.

Kader, A. A., Morris, L. L., Stevens, M. A., \& Albright-Holton, M. (1978). Composition and flavor quality of fresh Market tomatoes as influenced by some post-harvest handling procedures. Journal of American Society for Horticultural Science, 113(5), 742-745. 
Lee, J. M. (1994). Cultivation of grafted vegetables. I. Current status, grafting methods and banefits. Hortscience, 29, 235-239.

Lopes, C. A., \& Mendonça, J. L. (2016). Reação de acessos de jurubeba à murcha bacteriana para uso como porta-enxerto em tomateiro. Horticultura Brasileira, 34(3), 356-360. https://doi.org/10.1590/S0102-053620 16003008

Mendonça, J. L., Lopes, C. A., \& Moita, A. W. (2017). Compatibilidade de enxertia de híbridos interespecíficos de Solanum com tomateiro visando controle de patógenos de solo. Savannah Journal of Research and Development, 1(1), 34-38. https://doi.org/10.26512/savannahjournal.v1i1.7366

Peil, R. M. (2003). A enxertia na produção de mudas de hortaliças. Ciência Rural, 33(6), 1169-1177. https://doi.org/10.1590/S0103-84782003000600028

Ribeiro, A. C., Guimarães, P. T. G., \& Alvarez, V. H. (1999). Recomendações para o uso de corretivos e fertilizantes em Minas Gerais ( $5^{\text {a }}$ aproximação, p. 359). Comissão de fertilidade do Solo do Estado de Minas Gerais, Viçosa, MG.

Ribeiro, M. N. G. (1976). Aspectos Climatológicos de Manaus. Acta Amazonica, 6(2), 229-233. https://doi.org/10.1590/1809-43921976062229

Riga, P. (2015). Effect of rootstock on growth, fruit production and quality of tomato plants grown under low temperature and light conditions. Hortic. Environ. Biotechnol., 56(5), 626-638. https://doi.org/10.1007/s135 80-015-0042-0

Rouphael, Y., Schwarz, D., Krumbein, A., Colla, G. (2010). Impact of grafting on product quality of fruit vegetables. Sciencia Horticulturae, 127(2), 172-179. https://doi.org/10.1016/j.scienta.2010.09.001

Sakiyama, R., \& Stevens, M. A. (1976). Organic acid accumulation in attached and detached tomato fruits. Journal of the American Society for Horticultural Science, 101, 394-396.

Silva, F. A. S., \& Azevedo, C. A. V. (2016). The Assistat Software Version 7.7 and its use in the analysis of experimental data. Afr. J. Agric. Res., 11(39), 3733-3740. https://doi.org/10.5897/AJAR2016.11522

Sirtoli, L. F., Cerqueira, R. C., Rodrigues, J. D., Goto, R., \& Braga, C. L. (2011). Enxertia no desenvolvimento e qualidade de frutos de tomateiro sob diferentes porta-enxertos em cultivo protegido. Scientia Agraria Paranaensis, 10(3), 15-22.

Soare, R., Dinu, M., \& Babeanu, C. (2018). The effect using graftes seedlings on the yield and quality of tomatões grown in greenhouses. Horticultural Science, 45, 76-82. https://doi.org/10.17221/214/2016 -HORTSCI

Zenebon, O., Pascuet, N. S., \& Tiglea, P. (2008). Métodos fisico-químicos para análise de alimentos (p. 1020). São Paulo: Instituto Adolfo Lutz.

\section{Copyrights}

Copyright for this article is retained by the author(s), with first publication rights granted to the journal.

This is an open-access article distributed under the terms and conditions of the Creative Commons Attribution license (http://creativecommons.org/licenses/by/4.0/). 